\title{
O DIREITO AMBIENTAL NO BRASIL: EVOLUÇÃO HISTÓRICA E A RELEVÂNCIA DO DIREITO INTERNACIONAL DO MEIO AMBIENTE
}

\author{
GEORGETTE NACARATO NAZO* \\ TOSHIO MUKAI**
}

\begin{abstract}
I - Introdução. II - Pródromos do Direito Ambiental Brasileiro: a) As Ordenações e a Legislação Portuguesa; b) - Brasil Colônia; c) Período do Império; d) - Período Pós-Republicano. II - Marcos históricos da evolução do Direito Ambiental: I - Década de 1960/70; 2 - Década de 1970/80; 3 - Década de 1980/90. 4 - Momento atual e futuro. IV O Direito Internacional do Meio Ambiente: Sua relevância para o Brasil e a dimensão do Direito Internacional. a) Direito Internacional como sinônimo de Direito Internacional Público ou Direito das Gentes. b) Direito Internacional subdividido em Direito Internacional Público e Direito Internacional Privado. c) Direito Internacional como Direito das Relações Internacionais. V-Fontes. 1) Direito Interno. 2) Direito Internacional. VI - Direito Internacional do Meio Ambiente. a) Primeira fase. b) Segunda fase. c) Análise de suas fontes. VII - Conclusão.
\end{abstract}

\footnotetext{
* Advogada, Doutora em Direito - USP. Professora de Direito Internacional (aposentada) da Facuidade de Direito - USP. Orientadora de Mestrado e Doutorado. Professora Titular de Direito Ambiental e Direito Internacional do Meio Ambiente da F.D. da Fundação Armando Alvares Penteado - FAAP - Professora orientadora de pós-graduação na Faculdade de Direito de Guarulhos (UNG) - Membro da "International Law Association - Branch of Brazil" (ILA Londres) - Membro Conselheiro do Instituto de Direito Internacional e Relações Internacionais - IDIRI (São Paulo - USP) - Acadêmica da Academia Paulista de Direito (APD) - Membro da Associação Brasileira dos Advogados Ambientalistas (ABAA) - Membro da Sociedade Amigos da Marinha (SOAMAR/SP Diretora de Cultura) - Membro da Sociedade Brasileira de Direito Internacional (R.J.).

** Mestre e Doutor em Direito do Estado (USP). Secretário da Sociedade Brasileira de Direito do Meio Ambiente e membro da Comissão de Meio Ambiente do Conselho Federal da OAB Membro do Instituto dos Advogados Brasileiros.
} 


\section{$I$ - Introdução}

Devemos iniciar nossa incursão pela história do Direito Ambiental, tendo em conta a observação oportuna e racionalizante de Heisenbeg ("La Nature dans la Psyque Contemporaine", Paris, Galimard, 1962):

"A consideração da natureza como algo distinto do mundo divino só começou a firmar-se a partir do século XVIII. A natureza, não mais cenário participante da vida divina e humana, tornou-se objeto indiferente e homogêneo das experiências científicas. $O$ termo natureza passou a designar muito mais uma descrição científica da natureza, do que ela mesma. As montanhas, as plantas, os rios, as fontes, os astros celestiais e os próprios animais foram morrendo e desaparecendo aos poucos do cenário humano, reduzidos a equações matemáticas, fórmulas científicas, esquemas racionais e pragmáticos, elementos físicos do universo". Eis aí os males originais de tudo.

É a afirmação da cultura antropocêntrica, do racionalismo científico e do triunfo do liberalismo.

E, assim, começou-se a falar em "ecossistema", formado pelo "sistema natural", incluído aí o meio físico e biológico (solo, vegetação, animais, habitações, água etc.) e o "sistema cultural" consistindo do homem e de suas atividades (Cf. Suetônio Mota, Planejamento Urbano e Preservação Ambiental, Ed. Verde Pantanal, 1990, p. 32).

O termo "ecologia" deve-se a Ernst Haeckel (Generalle Morphologie der Organismen, 1866), "designando o estudo da influência do ambiente sobre os animais (do grego: oikos = casa/logos = ciência)" e definida como "a investigação das relações totais do animal tanto com seu ambiente orgânico como inorgânico" (aut., cit., p. 32).

Enfim, o conceito de "ecossistema" denomina todas as interações do meio físico com a espécie que nele habita e vive.

Outra expressão que significa a mesma coisa é, como se sabe, "meio ambiente", que, não obstante contenha um pleonasmo, segundo autores portugueses, se consagrou na literatura especializada.

Já o direito que rege e disciplina a proteção, a preservação e a recuperação desse "meio - ambiente" ganhou várias denominações, tais como Direito Ecológico, Direito do Meio - Ambiente, Direito Ambiental, sendo, esta última denominação, a mais difundida.

Há várias discussões sobre o verdadeiro sentido e conceito mais aceitável do Direito Ambiental. Não é o lugar aqui para tal divagação.

Importa-nos examinar, neste trabalho, a evolução histórica, no Brasil, desse Direito, nos seus aspectos legislativos, doutrinários e jurisprudenciais.

\section{II - Pródromos do Direito Ambiental Brasileiro}

\section{a) - As Ordenações e a Legislação Portuguesa}

Como ilustram vários autores, já a legislação portuguesa protegia as árvores, os animais e as águas. 
Assim, "as Ordenações Afonsinas, no Livro V, título LVIII, proibiam o corte de árvores frutíferas; o Livro V, título LXXXIII, das Ordenações Manoelinas, vedava a caça de perdizes, lebres e coelhos com redes, fios, bois ou outros meios e instrumentos capazes de causar dor e sofrimento na morte desses animais; as Ordenações Filipinas protegiam as águas, no Livro LXXV, título LXXXVIII, parágrafo sétimo, punindo com multa quem jogasse material que sujasse ou viesse a matar os peixes".

Ademais, "o corte deliberado de árvores frutíferas foi proibido por ordenação determinada pelo rei D. Afonso IV, em 12 de março de 1393, sendo que aí "se tipificava o corte de árvores de fruto como crime de injúria ao rei, tamanha a preocupação com a proteção florestal". ${ }^{2}$

Quanto à proteção dos animais, mais ainda das aves, "uma previsão do rei D. Diniz, de 9 de novembro de 1326, equiparava o furto das aves para efeitos criminais a qualquer outra espécie de furto". ${ }^{3}$

\section{b) Brasil Colônia}

Foi neste período que se iniciou a comercialização do pau-brasil, tendo sido essa "a primeira riqueza permutável, geradora, conseqüentemente, do primeiro contrato de arrendamento pelo período de três anos, entre a Coroa Portuguesa e um consórcio de cristãos-novos, liderado por Fernão de Loronha ou Noronha". 4

As Ordenações Manuelinas trouxeram normas mais detalhadas.

O título LXXXIII do livro I proibia a caça de coelhos e determinava o respeito às crias, nos meses de março, abril e maio, condenando o caçador que tivesse descumprido a lei ao pagamento de "mil reais", além da perda dos cães e das armadilhas utilizadas na caça.

Introduziu-se aí, já naquela época, um zoneamento ambiental, pois que havia a vedação da caça em determinados lugares, tais como Lisboa, Santarém, Coimbra, prevendo-se recompensa para quem acusasse o caçador". 5

No título $\mathrm{C}$ dessas Ordenações encontra-se norma muito significativa para nós. Ann Helen Werner ${ }^{6}$ informa-nos que esse título mantinha a tipificação, como crime, do corte de árvores frutíferas.

As penas eram: aquele que cortasse ou causasse dano à árvore de fruto, cujo valor fosse superior a "quatro mil reais" era açoutado e degredado pelo período de quatro anos. Para a hipótese de ter a árvore valor igual ou superior a "trinta cruzados", a pena para o infrator era o degredo permanente para a Ilha de São Thomé.

1 cf. Vladimir Passos de Freitas, “A Constituição Federal e a Efetividade das Normas Ambientais", tese de doutorado na Univ. Fed. PR (inédito), 1998, p.9

2 cf. Ann Helen Werner. "Legislação Ambiental do Brasil" - Subsídios para a História do Direito Ambiental" Forense - Rio, 1991, p. 5.

3 ob. cit. p.5.

4 ob. cit. p. 7.

5 ob.cit. p. 10.

6 ob. cit. p. 11 
Conta-nos, ainda, a autora que "a crescente devastação das floresta em solo português, ocasionada pelo corte desmedido das árvores cuja madeira era grandemente utilizada para a construção de navios, leva Dom Filippe, em 9.6.1594, a expedir uma carta de regimento, que contém um verdadeiro zoneamento ambiental, na qual delimita as áreas das matas que deveriam ser guardadas"?

Ainda, vê-se que em 5.06.1595, "o monarca expede um alvará mandando compilar todas as leis de Portugal". Ao depois, o filho de igual nome, após a morte de Filippe II da Espanha, em 11.01.1603, expede lei aprovando as Ordenações do Reino de Portugal, conhecidas como Ordenações Filipinas, obrigatórios no reino e nas colônias portuguesas, tendo vigorado no Brasil, ainda depois de decretado o C. Civil, através da Lei ${ }^{\circ} 3.071$, de 1.01.1916". ${ }^{8}$

$\mathrm{O}$ Título LXXV do Livro $\mathrm{V}$ mantém a proibição do corte de árvores frutíferas, incluindo o Brasil como local para cumprimento de pena de degredo definitivo pelo infrator que cortasse as referidas árvores de valor superior a "trinta cruzados".

Aparece, em 12 de dezembro de 1605, a primeira lei de proteção florestal do Brasil conhecida como o "Regimento do Pau-Brasil".

E, enfim, "em relação à legislação ambiental, editada para vigorar no Brasil Colônia, vamos encontrar várias determinações reais sob a forma de leis, alvarás, cartas régias e regimentos". 9

Um marco dessa época foi a instalação do Jardim Botânico do Rio de Janeiro, por decreto de D. João VI, de 13.6.1808.

\section{c) Período do Império}

Promulgada a Constituição Imperial de 25.03.1824 determinou-se ali a elaboração de um Código Civil e outro Criminal.

Neste período, "em 1830, é promulgado o Código Penal, com dois dispositivos (arts. 178 e 257), que estabeleciam penas para o corte ilegal de madeiras. Avançava na legislação extravagante a teoria da reparação do dano ecológico e no ano de 1850 é promulgada a Lei $n^{\circ} 601$, conhecida como a "Lei das Terras". Esta lei obrigava o registro de todas as terras ocupadas e impedia a aquisição das devolutas, a não ser por compra. Em seu artigo $2^{\circ}$, punia o dano pela derrubada de matas e queimadas, responsabilizando o infrator, " civilmente, com o pagamento de multa de cem mil réis e, penalmente, com a prisão que poderia variar de dois a seis meses". ${ }^{10}$

Ainda, informa-nos a autora: "Durante esse período, ocorrem muitos grandes melhoramentos urbanísticos, entre eles a inauguração da estrada de ferro D. Pedro II. É criado no Rio de Janeiro, em 1838, o Instituto Histórico e Geográfico Brasileiro e o Arquivo Nacional". ${ }^{11}$

\footnotetext{
7 ob. cit. p. 15.

8 ob. cit. p. 15.

9 ob. cit. p. 25.

10 ob. cit. p. 57.

11 ob. cit. p. 57.
} 
Outro ponto saliente a ser registrado é que "a Floresta da Tijuca, na região das matas da Tijuca, teve sua área rearborizada a partir de 1862, sob a direção do seu primeiro administrador, o Major Manoel Gomes Archer" e "teve como seu empreendedor o Imperador D. Pedro I, sendo um dos maiores símbolos da ecologia e do desenvolvimento do Império do Brasil com a questão ambiental". ${ }^{12}$

\section{d) Período Republicano}

Neste período (pós República, imediatamente), a Constituição Republicana de 1891 previu no seu art. 34, inciso XXIX, a competência da União para legislar sobre suas minas e terras.

O Código Civil, de $1^{\circ}$ de janeiro de 1916, previu nos seus arts. 554 e 555 a reprimenda ao uso nocivo da propriedade e, no art. 582, concede ao dono do prédio vizinho ameaçado, a possibilidade de solicitar o embargo de obras de chaminés, fogões ou fornos.

Informa-nos Ann Helen Wainer ${ }^{13}$ que "em 31 de dezembro de 1923, com o Decreto $\mathrm{n}^{\circ} 16.300$, que dispôs sobre a saúde e saneamento, importante passo foi dado em favor do controle da poluição, ao proibir instalações de indústrias nocivas e prejudiciais à saúde de residências vizinhas" e que, o Decreto Legislativo ${ }^{\circ} 5.481$, de 25.06.1929, veio regular o direito da propriedade imobiliária no plano horizontal" (expressão que se refere aos prédios de apartamentos, posto que aqui implica a superposição de vários planos horizontais superpostos).

A Constituição de 1934, no seu art. 10, estabelecia a competência concorrente da União e dos Estados para proteger as belezas naturais e os monumentos de valor histórico e artístico.

Nesta década (de 30) aparecem os primeiros diplomas legais setoriais, que iniciam a proteção específica do meio ambiente. Assim. o Decreto $\mathrm{n}^{\circ} 24.645$, de 10 de julho de 1934 que protegia os animais e o Decreto $\mathrm{n}^{\circ} 24.643$, de 11.7.1934, o código de Águas, com um capítulo sobre "Águas Nocivas". A exploração da caça e pesca foi prevista no art. 88 desse Código.

Já a Constituição de 1934 previa a competência para legislar sobre a fauna e a caça, dando competência privativa para tal à União, sem, entretanto, excluir a competência estadual. A Carta de $37 \mathrm{em}$ seu art. 16 dava competência privativa à União para legislar sobre caça, porém, no art. 18, permitia igualmente ao Estado legislar sobre a matéria para suprir lacunas e atender às peculiaridades regionais. A Constituição de 1946 também apontava para a União, quanto à caça, mas não excluía a competência estadual.

Apareceu em 1943, o primeiro Código de Caça entre nós Decreto-lei n ${ }^{\circ} 5.894$, de 20.10.43).

Além disso, "editou o Governo Federal, em 1954, a Lei $n^{\circ} 2.312$, que, em cumprimento ao receito constitucional, estabelecia normas gerais sobre defesa e

12 ob. cit. p. 59

13 ob. cit. p. 66. 
proteção da saúde, regulamentada apenas em 21.01.1961, através do Decreto $\mathrm{n}^{\circ}$ 49.974 - A", que se tornou mais utilizado e conhecido do que a própria Lei, conhecido que ficou como o Código Nacional de Saúde. ${ }^{14}$

Deve ser registrado ainda o aparecimento do nosso primeiro Código Florestal, através do Decreto-Lei ${ }^{\circ} 23.793$, de 23.01.34.

Em 1937, registre-se ainda, a edição do importante Decreto-Lei $n^{\circ} 25$, de 30 de novembro, que disciplinou a proteção do patrocínio histórico e artístico nacional.

Também é desse período o Código Penal que trouxe vários artigos protetivos da saúde, indiretamente, protegendo o meio ambiente. Por exemplo, o art. 165 dispõe sobre dano em coisa de valor artístico, arqueológico ou histórico.

\section{III - Marcos históricos da evolução do Direito Ambiental}

\section{I- Década de 1960/1970}

Como já dito, em 21.01.1961, foi editado o Decreto ${ }^{\circ} 49.974-\mathrm{A}$, denominado Código Nacional de Saúde, que trouxe várias regras que, indiretamente, disciplinaram questões ambientais, embora, mais especificamente, as questões atinentes à saúde (arts. 32 a 44 ).

Em 26.9.1967, como que a complementar tal diploma legal, aparece a Lei $\mathrm{n}^{\circ}$ 5.318, de 26.09.1967, criando o Conselho Nacional de Saneamento, vinculado ao Ministério do Interior.

Quanto às águas, o Decreto $\mathrm{n}^{\circ} 50.877$, de 29.06 .1961 , considerava poluição "qualquer alteração das propriedades físicas, químicas e biológicas das águas, que possam importar em prejuízo à saúde, à segurança e ao bem-estar das populações e ainda comprometer sua utilização para fins agrícolas, industriais, comerciais e, principalmente, a existência normal da fauna aquática".

É neste período que surgem os principais diplomas legais, já com uma preocupação mais concreta com a proteção ambiental.

No Estado de São Paulo é criada uma autarquia denominada FESB — Fomento Estadual de Saneamento Básico, com uma entidade administrativa denominada CETESB - Centro Tecnológico de Saneamento Básico, que iria se tornar o principal órgão de combate à poluição no Estado. ${ }^{15}$

Foi criada também por essa época a SUSAM - Superintendência de Saneamento Ambiental e na esfera municipal foi celebrado, entre os municípios vizinhos à Capital e o Governo do Estado, um convênio para a criação da CICPAA Comissão Intermunicipal de Controle da Poluição da Águas e do Ar. ${ }^{16}$

14 cf. Eurico de Andrade Azevedo e Adilson Abreu Dallari, "Fundamentos Legais para o Combate à Poluição Ambiental", in RDP n 16/295.

15 Cf. Eurico de Andrade Azevedo/Adilson Abreu Dallari, art. cit. p. 295

16 art. cit. p. 296. 
Em 28.02.1967 é criado o Conselho Nacional de Controle da Poluição, através do Decreto-Lei $n^{\circ} 303$, extinto, ao depois, pela Lei $n^{\circ}$ 5.318, de 26.9.1967.

Também nesse mesmo dia é promulgado o Decreto-Lei n ${ }^{\circ} 221$, que dispôs sobre a proteção de estímulo à pesca (Código da Pesca).

Aparecem neste período diplomas importantíssimos como o Código Florestal (Lei $n^{\circ} 4.771$, de 18.09.1965); a Lei de Proteção à Fauna ( ${ }^{\circ}$ 5.197, de 31.01.1967), o Código da Pesca (Decreto-Lei ${ }^{\circ}$ 221/67).

$\mathrm{Na}$ doutrina, aparece a primeira obra de cunho ambiental pela pena magnífica de Osny Duarte Pereira ${ }^{17}$, mas, ainda sem uma abordagem essencialmente voltada para a proteção ambiental. Em 1961, surge a Lei $n^{\circ} 3.964$, que protege os monumentos arqueológicos e pré-históricos e, em 1962, surge a Lei ${ }^{\circ} 4.132$, definindo os casos de desapropriação por interesse social, sendo que o art. $2^{\circ}$, inc. V, prevê a desapropriação para a proteção do solo e preservação dos cursos e mananciais de água, bem como de reservas florestais. Marco importante é o aparecimento do clássico "Direito de Construir", de Hely Lopes Meirelles, em 1961. ${ }^{18}$

Ainda, em 1961, a Lei Delegada $\mathrm{n}^{\circ} 10$ cria a SUDEP - Superintendência do Desenvolvimento da Pesca, extinta, ao depois, pela Lei $n^{\circ}$ 7.735, de 22.2.1989, passando suas atribuições para o IBAMA.

Registre-se, ainda, a edição, em 28.02.1967, do Decreto-Lei n 227 (Código de Mineração) pois a questão minerária tem inegáveis reflexos no tema do meio ambiente.

O Decreto $n^{\circ} 62.127$, de 16.01.1968 (Código Nacional de Trânsito) trouxe regra importante sobre o uso, nos veículos automotores, de instrumentos que diminuam ou impeçam a poluição do ar.

\section{II - Década de 1970/1980}

Esta década é a mais importante para início da consolidação das preocupações ambientalistas, pois é em 1972, em Estocolmo, que, sob o patrocínio da ONU, realiza-se a célebre Conferência sobre o Meio Ambiente (de 5 a 16 de junho de 1972).

Adianta-nos Ann Helen Werner ${ }^{19}$, que, antes, no Rio de Janeiro, em agosto de 1971, ocorreu a VIII Reunião Internacional dos Magistrados, onde se debateu a relação do jurista com o meio ambiente.

O trabalho jurídico pioneiro na matéria, nesta nova era da consolidação do Direito Ambiental, foi o do Prof. Sérgio Ferraz ${ }^{20}$.

Em seguida, registramos a obra de Diogo de Figueiredo Moreira Neto ${ }^{21}$.

17 “Direito Florestal Brasileiro, Rio, Borsoi, 1950

18 "Ed. Rev. dos Tribunais, 1" edição, 1961.

19 ob. cit. p. 88.

20 "Direito Ecológico: Perspectivas e Sugestōes. Rev. Consultoria - Geral do R.G.S. - Porto Alegre v. 2. - p. 43-52, 1971.

21 Curso de Direito Administrativo - 1^ ed. - Forense - Rio, 1975. 
Outra obra sua, expressiva e também pioneira, foi "Introdução ao Direito Ecológico e ao Direito Urbanístico".22

Em seguida, Armando H. Dias Cabral publica uma monografia sobre o assunto, premiada no I Simpósio Nacional de Ecologia, Curitiba, 1978, intitulada “ A proteção ambiental e seus instrumentos jurídicos".

Outros trabalhos doutrinários foram produzidos nesta década. Dentre eles podemos citar os seguintes:

a) artigo de Paulo Affonso Leme Machado, intitulado "Apontamentos sobre a repressão legal da poluição;" 23 $\cos ; " 24$

b) artigo do mesmo autor intitulado "Urbanismo e Poluição: aspectos jurídi-

c) artigo de Walter Ceneviva, intitulado "Controle da Poluição;" 25

d) artigo de nossa autoria intitulado "Âmbito, Competências e Instrumentos Legais e Jurídicos da Proteção Ambiental no Brasil;" 26

e) artigo de Freitas e Terçarolli, intitulado "Contravenção florestal, à caça e à pesca" (Vladimir Passos de Freitas e Carlos Eduardo); ${ }^{27}$

f) livro de Cid Tornanik Pompeu, "Regime Jurídico das Águas Públicas;" 28

Ainda, no campo legislativo citam-se:

a) a Lei $n^{\circ} 6.151$, de 4 de novembro de 1974 , que além de ter se constituído no Plano Nacional de Desenvolvimento, traçou diretrizes sobre o meio ambiente;

b) Decreto $n^{\circ} 73.030 / 1973$, que criou a Secretaria Especial do Meio Ambiente;

c) Decreto-Lei ${ }^{\circ} 1.413$, de 1975 , que dispôs sobre as áreas críticas de poluição (art. $4^{\circ}$ ), com a obrigatoriedade, para elas, de um "esquema de zoneamento urbano";

d) Decreto $\mathrm{n}^{\circ} 76.389$, de 1975 que indicou as áreas críticas de poluição.

e) Surge, no Estado de São Paulo, a Lei n ${ }^{\circ}$ 997, de 31.05.1976, que instituiu o Sistema de Prevenção e Controle da Poluição do Meio Ambiente, no Estado, sendo o seu Regulamento o Decreto ${ }^{\circ}$ 8.468, de 08.09.1976;

f) Registre-se também, em nível do Estado de São Paulo, o Decreto n ${ }^{\circ} 13.069$, de 29.12.1978, que aprovou normas técnicas especiais relativas ao Saneamento Ambiental nos Loteamentos Urbanos ou para fins urbanos;

g) Também no âmbito do Estado de São Paulo, surge a Lei $n^{\circ} 1.817$, de 27.10.1978, que disciplinou o zoneamento industrial na Região Metropolitana de São Paulo; Decreto $\mathrm{n}^{\circ}$ 13.095, de 5.01.1979, aprovou o Regulamento da Lei $\mathrm{n}^{\circ}$ $1.817 / 78$.

h) Lei estadual $\mathrm{n}^{\circ} 2.952$, de 15.07 .1981 , alterou o quadro II, a que se refere o art. $8^{\circ}$ da Lei $n^{\circ} 1.817 / 78$.

Editora Forense - Rio - 1975

3 Revista dos Tribs. v. 458, p. 281 - dez. de 1973.

24 Revista dos Tribs. v. 469 , p. 34 - nov. 1974

25 Folha de S.Paulo, 2 de outubro de 1977. Caderno 2. p. 25.

26 Revista Município Paulista n ${ }^{\circ}$ 9/11, abr./dez. - 1978, p. 13-32

27 Revista dos Tribunais. v. 520, p. $340-343$ - fls. 1979

28 CETESB, S. Paulo, 1976. 
i) Lei estadual $n^{\circ} 898$, de 18.12 .1975 , que dispõe sobre a proteção aos mananciais da Região Metropolitana da Grande São Paulo;

j) Lei $n^{\circ} 1.172$, de 17.11.1976, que complementou a Lei $n^{\circ} 898 / 75$;

k) Decreto $n^{\circ}$ 9.714, de 19.04.1977, Regulamento da Lei de Mananciais;

l) Decreto $\mathrm{n}^{\circ} 79.367$, de 9.03 .1977 - dispôs sobre normas e padrões de potabilidade da água;

m) Lei $\mathrm{n}^{\circ}$ 6.513, de 20.12.1977, que dispôs sobre a criação de áreas especiais e de locais de interesse turístico;

n) Lei ${ }^{\circ} 6.662$, de 25.06 .1979 , que dispõe sobre a Política Nacional de Irrigração;

o) Decreto ${ }^{\circ} 84.017$, de 21.09.1979, que regulamenta os Parques Nacionais;

p) Lei ${ }^{\circ} 6.766$ de 19.12.1979, que dispõe sobre o parcelamento do solo urbano.

No campo judicial, em 1973 deu entrada no Fórum da Comarca de Itanhaém, SP, "aquela que certamente terá sido a primeira ação de natureza ambiental proposta no Brasil. O autor foi Ernesto Zwarg Júnior, que propôs ação popular contra a Câmara Municipal e o Prefeito, contra a aprovação das Leis $n^{\circ} 989$ e 990 , que permitam construções de prédios com até 15 andares, mesmo em vias não dotadas de redes de esgoto ou na orla marítima. Em 15.05.1974, o Juiz da Comarca proferiu sentença julgando a ação procedente, tendo sido essa sentença reformada pela $3^{\mathbf{a}}$ Câmara Civil do Tribunal de Justiça do E. de São Paulo" ${ }^{29}$

No campo dos eventos, realizou-se, em Curitiba, o Simpósio Nacional de Ecologia, em 1978. E, em 1979, realizou-se em Piracicaba, sob a coordenação de Paulo Afonso Leme Machado, o I Curso Internacional de Direito Comparado do Meio Ambiente, com a participação efetiva de mais de 10 professores de diversos países, quando então foi criada a Sociedade Brasileira de Direito do Meio Ambiente - SOBRADIMA, marco histórico na evolução doutrinária do Direito Ambiental Brasileiro.

A SOBRADIMA realizou diversos cursos internacionais, seminários e simpósios, em vários Estados do Brasil.

Dentre eles destacamos: 1981, Salvador, análise do projeto de lei da política nacional do meio-ambiente; 1983, São Paulo, análise do projeto de lei sobre o desenvolvimento urbano; 1985, Salvador, tema: gerenciamento costeiro e sugestões para a Constituição de 1988; 1986, Campo Grande, tema: Legislação da Fauna; 1987, Porto Alegre, tema: pesticidas, 1989, São Paulo, tema: resíduos perigosos e nucleares.

A SOBRADIMA colaborou na criação do CONAMA, integrando-o, de 1984 (sua instituição) até 1986 e participou do Comitê do Fundo de Interesses Difusos, de 1989 a 1991.

\section{c) - A década de 1980/1990}

Como disse Vladimir Passos de Freitas em sua tese de doutorado ${ }^{30}$, "na década de oitenta a evolução (do direito ambiental) se acelerou. Primeiro, por força da Lei 
da Política Nacional do Meio Ambiente (6.938, de 31.8.1981); depois em razão da Lei da Ação Civil Pública (7.347, de 24.7.1985); finalmente, com a entrada em vigor da nova Constituição Federal (5.10.1988). Nesses anos multiplicaram-se os simpósios visando a tutela do meio ambiente; artigos, organizações não governamentais e outras tantas iniciativas.

No âmbito das obras jurídicas, faz-se imprescindível mencionar duas publicações: a primeira é o clássico Direito Ambiental Brasileiro, de Leme Machado (S. Paulo, Rev. Tribs., 1982); a segunda é de Milaré, Ferraz e Néri Júnior, em 1984, sobre "A Ação Civil Pública e a Tutela Jurisdicional dos Interesses Difusos" (São Paulo, Saraiva, 1984)".

Ainda há que se citar: "Código de Águas", de Antônio Pádua Nunes ${ }^{31}$; “Loteamentos e Desmembramentos Urbanos" ${ }^{32}$, de Toshio Mukai, Alaor Caffé Alves e Paulo José Villela Lomar, Ed. Sugestões Literárias, S. Paulo, 1980, "Direito Penal Ecológico", de Paulo José da Costa Júnior e Giorgio Gregori ${ }^{33}$; “Comentários ao Código Florestal", de Juraci Perez Magalhães ${ }^{34}$; do mesmo autor, "Recursos Naturais, Meio-Ambiente - Sua defesa no Direito Brasileiro" 35; "Direito Urbanístico Brasileiro" de José Afonso da Silva ${ }^{36}$; "O Município e o Parcelamento do Solo Urbano", de Diógenes Gasparini ${ }^{37}$; "Direito e Legislação Urbanística no Brasil História - Teoria - Prática", de Toshio Mukai ${ }^{38}$; "Crimes contra a Natureza", de Vladimir e Gilberto Passos de Freitas ${ }^{39}$; "Curso de Direito Ambiental", de Paulo Bessa Antunes ${ }^{40}$ e "Introdução ao Direito Ambiental", de Carlos Gomes de Carva1ho ${ }^{41}$; artigo intitulado: “Aspectos Jurídicos da Proteção Ambiental no Brasil”, de Toshio Mukai, RDP 73/288 - jan./mar. 1985; artigo intitulado: "Legislação, Meio Ambiente e Autonomia Municipal", de Toshio Mukai, RDP 79/125 - jul./set. 1986.

Ainda, quanto à evolução histórica legislativa, não podemos deixar de registrar o surgimento da Lei ${ }^{\circ} 6.803$, de 2 de julho de 1980, que determinou diretrizes básicas para o zoneamento industrial nas áreas críticas de poluição; seu mérito maior foi o de ter introduzido, pela primeira vez no direito ambiental brasileiro, o instrumento do estudo de impacto, por sugestão de Paulo Affonso Leme Machado.

Surge também, o Decreto ${ }^{\circ} 88.351$, de 1.06 .1983 , que criou o CONAMA Conselho Nacional do Meio Ambiente, previsto no inc. II do art. $6^{\circ}$ da Lei $n^{\circ}$

312 vols. - Rev. Tribunais, São Paulo, 1980.

32 Ed. Sugestões Literários, São Paulo, 1980.

33 CETESB - São Paulo, 1981.

34 Senado Federal, Brasília, 1980.

35 Ed. da F.G.V. - Rio de Janeiro, 1982.

36 Ed. Revista dos Tribunais, São Paulo, 1981.

37 Ed. Saraiva, $2^{a}$ ed. São Paulo, 1988.

38 Ed. Saraiva, São Paulo, 1988, c/prefácio de Hely Lopes Meirelles.

39 Ed. Revista dos Tribunais, São Paulo, 1990 ( $2^{a}$ edição).

40 Ed. Renovar, Rio, 1990.

41 Ed. Verde-Pantanal, Cuiabá, 1990. 
6.938/81. É editada pelo CONAMA a resolução $\mathrm{n}^{\circ} 01$, de 23.01.1986, que, em seu artigo $5^{\circ}$, conceituou o que seja impacto ambiental.

A Lei $n^{\circ} 7.804$, de 1989 , que alterou a Lei $n^{\circ} 6.938 / 81$, no seu art. $3^{\circ}$, mandou substituir nos dispositivos das Leis 6.803/80, 6.902/81, e 6.938/81, onde couber, a expressão SCMA por IBAMA.

$\mathrm{O}$ inc. II do art. $8^{\circ}$ da Lei $\mathrm{n}^{\circ} 6.938 / 81$ foi tornado discricionário, quanto à exigência ou não do EIA/RIMA, pela Lei $n^{\circ} 8.028$, de 12.04.1990, adaptando-se, assim, ao texto constitucional (art. $225, \S 1^{\circ}$, IV).

Devem ser citados ainda:

a) Decreto $n^{\circ} 84.973$, de 29.7 .1980 , que dispõe sobre a co-localização de estações ecológicas e usinas nucleares;

b) Decreto-Lei $n^{\circ} 1.809$, de 7.10 .1980 , que instituiu o sistema de proteção ao programa nuclear brasileiro;

c) Decreto $n^{\circ} 86.176$, de 6.7.1981 e que regulamenta a Lei $n^{\circ} 6.513$, de 20.12.1977, que dispõe sobre a criação de áreas especiais e de locais de interesse turístico;

d) Decreto ${ }^{\circ} 89.336$, de 31.01.1984 que dispõe sobre as reservas ecológicas e áreas de relevante interesse ecológico;

e) a Lei $n^{\circ} 7.661$, de 16 de maio de 1988 , que institui o Plano Nacional de Gerenciamento Costeiro;

f) Lei ${ }^{\circ} 7.735$, de 22.02.1989, que criou o Instituto Brasileiro do Meio Ambiente e dos Recursos Naturais Renováveis - IBAMA;

g) Decreto $\mathrm{n}^{\circ}$ 97.946, de 11.07.1989, que dispõe sobre a estrutura básica do IBAMA;

h) Lei $n^{\circ} 7.803$, de 18.7.1989 que determina a obrigatoriedade de licença para a comercialização ou utilização de moto-serra;

i) Decreto ${ }^{\circ} 99.274$, de 6.06.1990, que regulamentou a criação de estações ecológicas e áreas de proteção ambiental e a Lei de Política Nacional do Meio Ambiente;

j) Lei $n^{\circ} 7.875$, de 13.11 .1989 , que dá nova redação a dispositivo da Lei 4.771 , de 15.09.1965;

k) Decreto $n^{\circ} 96.944$, de 12.10.1988 - cria o Programa de Defesa do Complexo de Ecossistemas da Amazônia Legal;

1) Lei $n^{\circ} 7.802$, de 11.07 .1989 - dispõe sobre a pesquisa, experimentação, a embalagem e rotulagem, o transporte, o armazenamento, a comercialização, a propaganda comercial, a utilização, a implantação, a exportação, o destino final dos resíduos e embalagens, o registro, a classificação, o controle, a infração e a fiscalização de agrotóxicos;

m) Decreto $n^{\circ} 98.816$, de 11.01.1990, que regulamentou a Lei $n^{\circ} 7.802 / 89$, que dispõe sobre agrotóxicos.

Finalmente, em termos legislativos, há que se registrar alguns comandos centrais sobre a matéria ambiental contemplados na Constituição de 5.10.1988. Registre-se que, até então, o tema meio ambiente era ausente de tratamento constitucional direto, como o faz a atual Constituição. 
Assim é que o artigo 170 da C.F. contempla, como um dos princípios gerais da atividade econômica, a defesa do meio ambiente (inc. VI) e no art. 225 concede um direito subjetivo público a todos de terem um meio ambiente ecologicamente equilibrado, equiparando-o aos bens de uso comum do povo, obrigando o Poder Público e a coletividade a defendê-lo e preservá-lo para a presente e futuras gerações.

Através do seu $\S 1^{\circ}$ obriga que o Poder Público tome as medidas concretas para a efetivação do disposto no "caput", através das ações que indica nos seus incisos I a VII.

No art. 23 contempla a competência comum na defesa do meio ambiente, dos três níveis de Governo, em caráter de cooperação; no art. 24 contempla a competência concorrente na matéria, sendo que à União cabe, aqui, legislar apenas sobre normas gerais.

Entretanto, e ainda, todos os níveis de Governo têm suas competências privativas na matéria, conforme a proteção ambiental interessar a mais de um Estado ou for de caráter nacional ou internacional (União), interessar a determinado Estado-membro ou a mais de um Município (Estados), ou interessar apenas localmente (Município). Tais competências estão abrigados pelo art. 21 (inc. IX e XX, XXIII, alínea “c”) e art. 22 (inc. II, IV, IX, XI, XII, XIV, XXVI), para a União; no art. 25 para os Estados (art. 25, $\S 1^{\circ}$ ) e no art. 30 (nos incisos I, II, VIII, IX) para os Municípios.

\section{IV - Momento atual (a partir de 1991) e futuro.}

Em termos históricos, podemos dizer que vivemos, a partir de 1991, um período de consolidação da matéria ambiental, sob todos os seus ângulos. No campo legislativo, houve a elaboração de novas normas que procuraram aperfeiçoar a legislação existente. Mas, esta ainda é bastante confusa, lacunosa, e, em, muitos pontos inconstitucional, por não terem sido recepcionados pela Constituição de 1988.

Como diplomas importantes desta década podemos citar:

a) Lei $\mathrm{n}^{\circ} 8.028$, de 12.04.1990, que alterou diversas disposições da Lei 6.938/81;

b) Decreto ${ }^{\circ} 1.298$, de 27 de outubro de 1994 - aprova o Regulamento das Florestas Nacionais;

c) Decreto $\mathrm{n}^{\circ} 1.775$, de 8.01 .1996 - dispõe sobre o procedimento administrativo de demarcação das terras indígenas:

d) Resolução ${ }^{\circ} 5$, de 5.08.1993 - disciplina os procedimentos mínimos para o gerenciamento de resíduos (CONAMA).

e) Resolução ${ }^{\circ}$ 6, de 19.09.1991 — dispõe sobre critérios para a desobrigação de queima de resíduos sólidos.

f) Resolução n 23, de 12.12.1996 - trata do controle de movimentos transfronteiriços de resíduos perigosos;

8) Portaria $n^{\circ}$ 95, de 31.07.1996 - institui o Cadastro de Estabelecimentos Comercializadores de Agrotóxicos.

9) Decreto $\mathrm{n}^{\circ}$ 2.210, de 22.04.1997 - Regulamento da Lei $\mathrm{n}^{\circ} 1.809$, de 7.10.1980 que institui o Sistema de Proteção ao Programa Nuclear Brasileiro (SIPRON); 
10) Resolução $\mathrm{n}^{\circ} 4$, de 20.11.1991 - Normas para o uso de portos, baías e águas por navios nucleares.

11) Lei $n^{\circ} 8.974$, de 5.01.1995, estabelece normas para o uso das técnicas de engenharia genética e liberação no meio ambiente de organismos geneticamente modificados e autoriza a criação da Comissão Técnica Nacional de Biossegurança;

12) Decreto $n^{\circ} 1.752$, de 20.12.1995 - Regulamenta a Lei $n^{\circ} 8.974 / 95$ e dispõe sobre a vinculação, competências e composição da Comissão Técnica Nacional de Biossegurança - CTNBio.

13) Lei $\mathrm{n}^{\circ}$ 9.433, de 8.01.1997 que institui a Política Nacional de Recursos Hídricos e cria o Sistema Nacional de Gerenciamento de Recursos Hídricos;

14) Resolução $n^{\circ} 001 / 90$, de 8.3.1990, do CONAMA, que disciplina a emissão de ruídos, contendo normas de combate à poluição sonora;

15) Resoluções $n^{\circ} 09$ e 10, de 6.12.1990, do CONAMA, que exige o EIA/RIMA na autorização para exploração mineral;

16) Lei $n^{\circ} 9.605$, de 12.02.1998 - dispõe sobre as sanções penais e administrativas derivadas de condutas e atividades lesivas ao meio ambiente;

17) Decreto $n^{\circ} 3.179$, de 21.09.1999 - Regulamenta a aplicação das sanções às condutas e atividades lesivas ao meio ambiente, previstas na Lei ${ }^{\circ}$ 9.605/98;

18) Resolução CONAMA ${ }^{\circ} 257$, de 30.06.1999 - disciplina o rejeito de pilhas e baterias que cotenham em suas composições substâncias específicas que causem impactos negativos ao meio ambiente.

19) Resolução CONAMA $n^{\circ} 256$, de 20.06.1999 - aprova norma sobre inspeção de emissões de poluentes e ruídos prevista no art. 104 da Lei $n^{\circ} 9.503 / 97$, que institui o Código de Trânsito Brasileiro.

20) Medida Provisória $n^{\circ} 1.874-13$, de 28.7.1999, que acrescenta dispositivo à Lei ${ }^{\circ}$ 9.605/98;

21) Medida Provisória ${ }^{\circ} 1.885-39$, de 28.7.1999, que dá nova redação aos arts. $3^{\circ} 16$ e 44 da Lei $n^{\circ} 4.771$, de 15.09 .1965 , e dispõe sobre a proibição do incremento da conversão de áreas florestais em áreas agrícolas na Região Norte e na parte norte da Região Centro-Oeste.

Na doutrina podemos destacar, dentre outros os seguintes trabalhos: a) "Direito Ambiental e a Questão Amazônica" ${ }^{42}$; b) "Meio Ambiente nos TribunaisJurisprudência" 43; "Direito Agrário e Meio Ambiente" 44; d) "Dicionário Jurídico do Ambiente" ${ }^{45}$; e) — "Direito Ambiental Sistematizado" 46 ; f) — "Dano Ambiental: prevenção, reparação e repressão" ${ }^{47} ; \mathrm{g}$ ) - "Direito Administrativo e Meio Ambiente" ${ }^{48}$; h) — "Política e Direito Agroambiental" ${ }^{49}$; i) — "Tutela Penal do

Org. Maria Cristina Dourado - UNAMAZ - n 8 - Belém - 1991.

43 ADCOAS, Rio, 1992

44 Octávio Mello Alvarenga, ed. Forense, Rio, 1992.

45 Carlos Gomes de Carvalho, Ed. Letras \& Letra, S.P., 1991

46 Toshio Mukai, Ed. Forense Univ., Rio, 1992

47 Coord. Antonio Herman V. Benjamin, Ed. Rev. Tribs., SP, 1993

48 Vladimir Passos de Freitas, Juruá Ed., Curitiba, 1993.

49 Ed. Forense, Rio, 1995. Octávio Mello Alveranga 
Patrimônio Cultural" 50; j) - "Amazônia perante o Direito: Problemas Ambientais e Trabalhistas" 51 ;) - "Direito Ambiental Internacional" 52; m) - "Manual de Direito Ambiental e Legislação Aplicável" 53 ; n) "Direito Ambiental Econômico" 54; o) - "Tutela Penal do Meio Ambiente" ${ }^{55}$; p) - "Direito Ambiental em Evolução" 56; q) "A Evolução do Direito Ambiental no Brasil" 57; "Questões Importantes referentes ao Mar" 58 .

Em 1999 surgiram ainda outras obras, dentre elas, podendo se destacar: 1) "A Problemática Ambiental" 59; 2) - "Mineração e Meio Ambiente na Constituição Federal" ${ }^{60}$; 3) - "Código Florestal Comentado" ${ }^{1}$; 4) — "Elementos de Direito Ambiental Brasileiro" ${ }^{62}$; 5) - "Biodiversidade e Patrimônio Genético no Direito Ambiental Brasileiro"63 - "As Águas no limiar do século XXI." ${ }^{64}$

No campo dos eventos, vários foram realizados, de inegável valia para o desenvolvimento do Direito Ambiental Brasileiro, mas nenhum teve tanta importância, para tal como a Conferência das Nações Unidas sobre Meio Ambiente e Desenvolvimento, realizada no Rio de Janeiro, a ECO-92, onde alguns diplomas legais internacionais importantes foram criados e que teve como consequiência a aceleração e a difusão da preocupação pelos problemas ambientais, no País e fora dele.

Durante essa Conferência, a SOBRADIMA, juntamente com o Centro Internacional do Direito Ambiental Comparado (Limoges-França) e com o Conselho Federal da $\mathrm{OAB}$, realizou seminário reunindo 150 juristas de todo o mundo.

Registre-se, ainda, fato da maior importância que foi a criação, pela Comissão de Meio Ambiente da OAB/SP, sob a presidência do Dr. Antonio Fernando Pinheiro Pedro de um grupo de juristas que iniciou os primeiros estudos, do que, ao depois, foi aperfeiçoado e se constituiu num Anteprojeto de Código Ambiental Nacional $(1993)^{65}$.

\footnotetext{
50 Ivete Senise Ferreira. Ed. Rev. Tribs., S. Paulo, 1995

51 Org. Roberto A. O. Santos/Wolf Paul, Belein, 1995, Univ. Fed. Pará

52 Geraldo Eulálio do Nascimento, Thex. Ed., Rio, 1995.

53 Celso Antonio Pacheco Fiorillo/Marcelo Abelha Rodrigues, M. Limonad, SP, 1996.

54 Cristiane Derani, M. Limonad, S. Paulo, 1997.

55 Luiz Paulo Sirvinkas, Ed. Saraiva, SP, 1998

56 Org. Vladimir Passos de Freitas, Juruá. Ed. Curitiba, 1998

57 Juraci Perez Magalhães. Ed. Oliveira Mendes, 1998

58 Coordenador: Georgette Nacarato Nazo - Soamar/SP ( $1^{\mathfrak{a}}$ edição), 1996 e Lilivros Editora ( $2^{\mathbf{a}}$ edição), 1999

59 Luiz César Ribas, Ed. de Direito, Leme, SP, 1999

60 Humberto Mariano de Almeida, LTR, SP, 1999

61 Luiz Carlos Silva de Moraes, Ed. Atlas, SP, 1999

62 Toufic Daher Deebeis. Liv. Univ. de Direito, S. Paulo, 1999

63 Celso Antonio Pacheco Fiorillo/Adriana Diaféria, Max Limonad, SP, 1999

64 Coordenador: Georgette Nacarato Nazo - Lilibros Editora, 1999

65 Ambos participamos de vários grupos de trabalho, cabendo a sistematização, redação final e das "Justificativas" à Georgette N. Nazo.
} 
Outro fato digno de registro foi a criação, em Salvador, da Associação Brasileira dos Advogados Ambientalistas - ABAA (1994).

O momento atual do Direito Ambiental é constituído por uma fase de concretização mais real desse Direito, para o que não se pode deixar de destacar o papel do Ministério Público, através de ações civis públicas, que tem intentado em diversos pontos do País. Também é de consolidação e de revisão da legislação ambiental existente principalmente, visando à regularização dos inúmeros defeitos que ela comporta, de ordem constitucional, de natureza formal, e de lacunas e imperfeições.

\section{IV - Direito Internacional do Meio Ambiente: sua relevância para o Brasil e a dimensão do direito internacional}

A preocupação com a temática ambiental conduz a um estudo inter e multidisciplinar, despertando a atenção de juristas e cientistas voltados para disciplinas extra jurídicas, ao examinarem a biosfera; com o intuito de protegê-la de deteriorações mais profundas e dos desequilíbrios que possam ocorrer por atividades humanas mal gerenciadas, em descompasso com leis, normas e princípios que buscam regramentos a essas atividades, ocupa-se, o jurista, com a tutela das mesmas, pelo esforço conjugado, examinando a quem devem ser carreadas obrigações jurídicas e responsabilidades, bem como em que bases devem estas serem estabelecidas e mensuradas.

Se, como examinado até aqui, o direito brasileiro tem elaborado disciplinamentos diferenciados, procurando atender às exigências que se impõem à sociedade, neste final de milênio, sob outro ângulo, no campo das relações internacionais, não tem o País descurado de afinar-se à cooperação indispensável no concerto das nações.

Com efeito, se bem quisermos assimilar os $\mathrm{X}$ princípios elencados no art. $4^{\circ} \mathrm{da}$ C.F. de 1988 que regem as relações internacionais, mister se torna examinar a dimensão do direito internacional na atualidade e suas especificidades, de sorte a melhor compreender o direito internacional ambiental de nomenclatura recentíssima, cujas fontes são, preponderantemente, internacionais. Alie-se, a isto, a circunstância de que $o$, conteúdo desse direito internacional do meio ambiente preenche as lacunas existentes nos direitos internos.

\section{DIMENSÃO DO DIREITO INTERNACIONAL}

Desta forma é preciso que se dê a dimensão do Direito Internacional e suas especificidades:

1) a concepção que designa o Direito Internacional como sendo exclusivamente Direito Internacional Público ou Direito das Gentes;

2) a que entende que no direito em geral há um ramo que se subdivide em dois outros: o Direito Internacional Público e o Direito Internacional Privado;

3) a que, sem se preocupar com subdivisões, concebe-o como o ramo do direito que se ocupa das relações internacionais de qualquer natureza. 
Historicamente, as duas primeiras expressões encontram justificativas, sendo que a $3^{\text {a }}$ é uma evolução moderna, atual, de sorte a enfocar e abordar realidades jurídicas novas, que a doutrina e a prática, nos dias que correm, vão ressaltando o valor e a especificidade crescente de determinadas relações jurídicas transnacionais e a unidade deste ramo do direito que é avocado a regulamentá-las.

Em outras palavras Direito Internacional, hoje, é expressão muito mais ampla e abrangente do que aquelas que vêm sendo utilizadas tradicionalmente pelos diferentes ordenamentos jurídicos dentro da comunidade internacional.

Procurarei explicar, de um modo suscinto, especialmente para aqueles que, não tendo formação jurídica, estão ligados a outras ciências extrajurídicas e, naturalmente, não só encontram dificuldades na prática, bem como podem estabelecer confusões quando se debruçam na leitura de doutrinadores alienígenas.

\section{1) Direito Internacional como sinônimo de Direito Internacional Público ou de Direito das Gentes:}

a) "Internacional Law" - é usado pelo direito anglo-americano com o sentido de Direito Internacional Público; mas, difere da concepção e do sentido que lhe dá o

b) Direito Alemão (Võlkerrecht) que, tradicionalmente é o Direito das Gentes;

c) Direito Francês: usa o epíteto: Direito Internacional Público.

Ora, o Direito Internacional Público, quanto aos sujeitos, às fontes e ao objeto tem a seguinte colocação tradicional:

Sujeitos: os Estados, com exclusão dos indivíduos (jus inter gentes);

Fontes: situam-se fora da vontade de um só Estado;

Objeto: regula somente a conduta dos Estados e não a dos indivíduos.

Todavia, este modo de fundamentar o Direito Internacional Público já está superado, porque:

Sujeitos: não só os Estados, mas as Organizações Internacionais, certas coletividades humanas (minorias) e, de certa forma, o homem, são outros sujeitos do Direito, Internacional Público. Ressalte-se, porém, que o homem é sujeito do D. I. Público, mas não tem personalidade jurídica internacional.

Fontes: nada existe acima da vontade dos Estados, mesmo que se pretenda considerá-las isoladamente; porém, vem sendo reiteradamente afirmado que em matérias outras que refogem ao Direito Internacional Público aplicam-se os princípios gerais de direito e firmam-se Tratados entre Estados, ou Convenções Internacionais, além de usos e práticas costumeiras.

Objetos: admite-se que, certas regras do Direito Internacional Público são direcionadas diretamente ao homem para regrar sua conduta. Exemplo característico: Declaração Universal dos Direitos do Homem; Infrações Internacionais; Direitos Humanos. 


\section{2) Direito Internacional subdividido em Direito Internacional Público e Direito}

Internacional Privado:

Esta pretensão em subdividi-lo é ambígua; transporta para o Direito Internacional, divisões próprias aos direitos internos de cada país e que nem sempre encontram coincidências de qualificações nos diferentes sistemas jurídicos.

Com efeito, se examinarmos a história moderna do Direito Internacional Privado, a partir de JOSEPH STORY (1834), veremos que o que ele denominou "direito internacional privado" colocava-se em contraposição ao "Internacional Law" dos norte-americanos (não sendo seguido pelos doutrinadores posteriores de seu país).

Os italianos chamam "Diritto Internazionale", genericamente, ambas as ramificações de Direito Internacional.

Em França, os efeitos de um ato administrativo estrangeiro são tidos como matéria de direito internacional privado.

Ora, se eu pretender fundamentar o Direito Internacional Público como voltado aos relacionamentos e à conduta entre Estados e o Direito Internacional Privado como tendo por objeto regular conflitos espaciais de leis internas dos Estados quando surja um fato estranho, um elemento estrangeiro (pessoas, bens, lugar, objeto de um negócio, nos relacionamentos transfronteiras dos países e pessoas destes países), vamos verificar outro ângulo importante: os conflitos de leis no espaço, tanto podem ser de leis de direito privado, corno de leis de direito público. O que interessa ressaltar é a metodologia moderna de atuação do Direito Internacional que antecede e informa o Direito Internacional Privado, porque este é direito interno de cada país, elaborado pelo legislador nacional para regular eventuais conflitos espaciais de leis internas (públicas ou privadas) dos Estados. Mas, está intimamente ligado e unido ao Direito Internacional Público, porquanto este, sendo um direito intergovernamental, tem sua razão de ser na facilitação das relações interindividuais corno essencial à sociedade internacional.

A jurisprudência da Corte Internacional de Justiça da Háia e de sua antecessora a Côrte Permanente de Justiça trilham esta colocação.

\section{3) Direito Internacional como Direito das Relações Internacionais:}

Esta acepção é bem mais larga e mais abrangente porquanto seu objeto são relações internacionais de toda a natureza.

No tocante às relações internas dentro de um Estado, as relações internacionais distinguem-se pela presença do elemento estranho (extranité, stranità, ou fato anormal), tendo em vista os sujeitos, o objeto do direito, ou o lugar em que os atos são produzidos.

Assim considerando, o Direito Internacional tomará as feições mais diferenciadas ao atendimento de relações específicas, na medida em que ao haja, correlação nos direitos internos. Deste modo, haverá - como dizem Francescakis e Alexandre Ch. Kiss - um Direito Internacional Público no sentido de um direito das relações entre Estados; e de outra parte, tantas ramificações do Direito Internacional regendo 
incidências internacionais correspondentes às divisões dos direitos internos (direito público, administrativo, processual, marítimo, comercial, civil, penal etc.).

Esta orientação moderna, atual e ainda em evolução, leva em conta a internacionalização que se vem acentuando em diversos setores da vida do Direito e que, dependendo do objeto próprio destes relacionamentos, tanto podem ter fontes internas, como fontes internacionais. Com base na origem destas fontes é que se poderá dividir o Direito, apondo-lhe o adjetivo internacional, antes ou depois de se enquadrar a disciplina e, mesmo assim, para fins didáticos, especialmente para a família dos sistemas romano germânicos:

a) se a fonte é internacional, o adjetivo internacional é colocado antes: Direito Internacional Penal;

Direito Internacional Administrativo

(é Direito Internacional Público);

b) se a fonte é interna, o adjetivo é colocado depois:

Direito Penal Internacional (conflito de leis);

Direito Administrativo Internacional;

(é Direito Internacional Privado).

\section{$V-$ Fontes}

Entendemos, neste passo, necessário cuidar-se da questão das fontes do Direito, antes de examinarmos a relevância do Direito Internacional do Meio Ambiente, porquanto nelas encontramos os métodos e processos de criação do direito, a hierarquia das normas a que o julgador, ou o árbitro recorrerá para fundamentar sua decisão.

Cabe lembrar, aqui, a doutrina de KELSEN:

"A norma que rege a criação de outra norma lhe é superior e a norma que é criada conforme às disposições de outra norma lhe é inferior. Nesse sentido, a norma jurídica superior é a fonte da norma jurídica inferior. A constituição de um Estado é a fonte das leis criadas de conformidade com a constituição. Uma lei é a fonte das decisões judiciárias que nela se fundam e uma decisão judiciária é a fonte de obrigações que ela impõe a uma das partes." 66

1) O direito pátrio tem como embasamento a Constituição Federal que norteia todo o ordenamento legislativo. Nos casos de omissão da lei, o intérprete encontra nos art. $4^{\circ}$ e $5^{\circ}$ da Lei de Introdução ao Código Civil, a fórmula para suprir tal dificuldade, in verbis:

"Quando a lei for omissa, o juiz decidirá o caso de acordo com a analogia, os costumes e os princípios gerais de direito" (art. $4^{\circ}$ da L.I.C.C.). 
"Na aplicação da lei, o juiz atenderá aos fins sociais a que ela se dirige e às exigências do bem comum" (art. $5^{\circ} \mathrm{da}$ LICC).

A própria dinâmica do direito deve acompanhar as relações humanas, atendendo à realidade histórico-cultural e as próprias necessidades da vida. As normas de um sistema jurídico não são imutáveis; muito ao contrário, devem acompanhar à realidade social e suas mutações. Ora, em certas ocasiões, o juiz encontra dificuldades em decidir, por não localizar nas normas do sistema normativo a solução adequada ao fato concreto "sub-exame", pois as normas não são todo o direito, porém parte dele. Constata a existência da lacuna e para preencher o vazio, socorre-se dos instrumentos, ou melhor, dos expedientes previstos no próprio sistema normativo, quais sejam os retro referidos nos arts. $4^{\circ}$ e $5^{\circ}$ da L.I.C.C. ${ }^{67}$; poderá, ainda, servir-se do direito comparado, da equiidade, como outros tantos subsídios à entrega justa da prestação jurisdicionaJ.

1) Para o Direito Internacional, as fontes formais, ou fontes propriamente ditas, encontram-se enunciadas no art. 38 do Estatuto da Corte Internacional de Justiça ${ }^{68}$, sediada na Háia, nos termos seguintes:

"1. A Corte, cuja função é decidir de acordo com o direito internacional as controvérsias que lhe forem submetidas, aplicará:

a) as convenções internacionais, quer gerais, quer especiais, que estabeleçam regras expressamente reconhecidas pelos Estados litigantes;

b) o costume internacional, como prova de uma prática geral aceita como sendo o direito;

c) os princípios gerais de direito, reconhecidos pelas nações civilizadas;

d) sob ressalva da disposição do art. 59, as decisões judiciárias e a doutrina dos juristas mais qualificados das diferentes nações, como meio auxiliar para a determinação das regras de direito.

2. A presente disposição não prejudicará a faculdade da Corte de decidir uma questão ex aequo et bono, se as partes com isto concordarem."

Analisando-se tais disposições, verificamos inexistir propriamente uma hierarquia entre elas, mas sim, uma classificação entre principais, secundárias ou subsidiárias e a complementar. Melhor esclarecendo: 1) principais: as letras " $a$ " - " $b$ " e "c" do item I; 2) subsidiárias: as da letra "d" do mesmo item; 3) complementar: a eqüidade do item 2.

Todavia, não se esgotam aí as fontes do Direito Internacional, por quanto ele pode emanar, ainda de atos unilaterais de um Estado, produzindo efeitos de direito, tanto internos, quanto internacionais, conforme o objetivo deste mesmo Estado.

67 Dentro da tridimensionalidade jurídica de MIGUEL REALE, podemos entender que o sistema do direito abrange um subsistema de normas, um subsistema de fatos e um subsistema de valores interdependentes.

68 Consulte-se "Direitos e Relações Internacionais" de Vicente Marotta Rangel, Edit. Rev. dos Trib., 1977 ( $5^{a}$ edição - Textos coligidos, ordenados e anotados), p. 68/86. 
Alie-se a isto, a circunstância de que o ato pode ser exarado pelo executivo, bem como pelo legislativo ou judiciário. Um exemplo característico examinado pela $\mathrm{CIJ}$ em 18/02/1951, ilustra o que afirmamos. Examinando uma questão sobre pesca, pronunciou-se a Corte deste modo: "a delimitação dos espaços marítimos tem sempre um aspecto internacional, ela não poderia depender da vontade única do Estado ribeirinho tal qual se exprime em seu direito interno"... "Se é verdade que o ato de delimitação é necessariamente um ato unilateral, porque apenas o Estado ribeirinho tem qualidade para proceder a respeito, em contraposição, a validade da delimitação em relação a terceiros depende do direito internacional" 69 .

A manifestação unilateral da vontade de um só Estado, na hipótese supra, é considerada atípica. Adquire contornos típicos em se tratando, por exemplo, de um protesto, uma renúncia, mudança de governo, reconhecimento de outro governo, ou ainda, quando o Estado silencia a respeito de determinados acontecimentos internacionais. Todavia, seja qual for o conteúdo do ato unilateral de um Estado, não tem ele o condão de criar obrigações que venham a onerar terceiros.

Alguns jusinternacionalistas consideram atos unilaterais, os que provêem das organizações intergovernamentais. São elas constituídas pela vontade de vários Estados, mas têm personalidade de Direito Internacional, distinta dos seus criadores, emitindo decisões, resoluções ou mesmo firmando convenções internacionais, todas dirigidas a outras pessoas de direito internacional, sejam elas: Estados, outras organizações internacionais, pessoas jurídicas de direito interno, indivíduos, tanto de cunho geral, como regionais. Entendemos, porém, que as organizações intergovernamentais como atores criadores de direito internacional, dotadas de personalidade jurídica internacional, não praticam ato unilateral típico tal como exposto anteriormente; o simples fato de firmarem convenções com outros atores de Direito Internacional, equipara-as a eles ao emitirem normas jurídicas que são também, outras tantas fontes de Direito Internacional.

\section{VI - O Direito Internacional do Meio Ambiente}

Retomando a premissa inicial desta exposição, podemos afirmar, agora, com melhor fundamento que o Direito Internacional Ambiental é um dos aspectos do Direito Internacional que está em evolução, adquirindo aos poucos, uma certa autonomia e cujas fontes são preponderantemente internacionais, vez que foi sendo construído por regras usuais de direito internacional.

Embora durante largo período, na sua evolução histórica, ficasse situado como um capítulo do Direito Internacional Administrativo que rege a atividade administrativa internacional, com normas próprias ao poder de polícia dos Estados e, conseqüentemente, onde aparecem conflitos espaciais de leis de direito público (área de atuação do Direito Administrativo Internacional, logo, Direito Internacional Privado), sua sistematização adquiria mais severos contornos quando a comunidade in- 
ternacional passou a tomar consciência da "desordem global da biosfera", como ressaltaram Eduardo J. Viola e Hector R. Reis, em artigo publicado em maio de 1990, na Revista "Lua Nova” (n² 20 - pg. 145/178).

Com efeito, desde o início, os tratados que buscaram a melhoria e preservação de espécies selvagens ou os acordos internacionais de 1911 para proteção às focas, como Convenções de 1902 para proteção de pássaros úteis à agricultura (Paris, 19.03.1902), tiveram um cunho nitidamente utilitarista.

No campo do Direito Internacional do Trabalho, em 1903 e 1904, Dullin e Paul Pic publicam livros específicos: "L’hygiene et la securité des travailleurs" e "Traité Elementaire de lésgislation industrielle", respectivamente.

Em 1913, a Conferência de Berna cuida dos riscos profissionais e a proteção dos trabalhadores.

Bem mais tarde, em 1937, a Organização Internacional do Trabalho (OIT) vota a Convenção $n^{\circ} 62$, relativa aos trabalhadores em edificações.

\section{A - Primeira fase do Direito Internacional Ambiental}

Todavia, foi na década de 60 que começou a despertar a preocupação com o estado geral do meio ambiente, em nível de governos, graças às pressões dos movimentos de opinião pública internacional.

Nesta época, surgem leis internas nos diferentes países, na busca de um regramento destinado a lutar contra a poluição de águas continentais, mar, ar e a salvaguardar determinadas zonas, criando-se órgãos administrativos especiais, ministérios ou agências internacionais-governamentais para o meio ambiente, bem como órgãos descentralizados. A evolução se faz quase paralela: disposições internas dos Estados e textos internacionais abraçando a necessidade de preservação ambiental.

Registre-se, no entanto, que o Brasil, bem antes (décadas de 30 e 40) já dispunha de códigos específicos para florestas, minas, águas.

Em 1961, na Carta Social Européia, seus signatários se comprometem a promulgar regulamentos de higiene e segurança no trabalho, seguida em 1964, no seio da OIT pela Convenção $n^{\circ} 120$ que estabelece a exigência de higiene no comércio e nos escritórios. São instrumentos reveladores da preocupação com a saúde do trabalhador.

Em 1968, o Conselho da Europa vota a Carta Européia das Águas, estabelecendo o princípio fundamental de que as águas não conhecem fronteiras. $\mathrm{E}$ a experiência, logo em seguida, veio demonstrar que não só as águas, como os oceanos e a atmosfera não têm fronteiras (Declaração sobre a poluição atmosférica) e formalização de Acordo Europeu sobre a limitação e emprego de determinados detergentes.

Podemos afirmar que estes instrumentos deram início à $l^{a}$ fase da era ecológica na Europa, motivando os Chefes de Estado e Governos dos Estados Africanos a votarem, também, em 68, a Convenção Africana para conservação da natureza e dos recursos naturais, substituindo assim a Convenção de Londres de 1933 firmada entre os países colonizadores. Esta Convenção da Organização da União Africana é tida como um modelo pelos princípios aí estabelecidos (criação de reservas, regulamen- 
tação da caça, da captura, da pesca e proteção especial de certas espécies: fauna e flora) não só no que tange às espécies, mas também a seu "Habitat", como a responsabilidade dos Estados que tenham, em seu território, uma espécie rara.

Ainda que se pretendesse deixar de lado, a Declaração Universal de Direitos do Homem (ONU, 1948), a Declaração Americana dos Direitos e Deveres do Homem, que não têm força coercitiva (são tidas como "soft law" de ponderável valor ético), a Convenção Americana sobre Direitos Humanos de São José da Costa Rica, 1969 e os Pactos Internacionais de Direitos Econômicos, Sociais e Culturais e Direitos Civis e Políticos (da ONU, 1966), trouxeram a tônica de assegurar os direitos fundamentais do homem: direito à vida, à liberdade, à saúde, ao trabalho, à educação para ter condições mínimas de desenvolvimento; seria impossível uma abordagem desses direitos sem que se levasse em consideração o meio em que ele vive. Daí resulta que desenvolvimento implica em melhor qualidade ambiental de vida.

Portanto, o Direito Internacional Ambiental tendeu a expandir-se de um modo globalizante universal interagindo com outros ramos do próprio direito e com outras ciências extra-jurídicas que o informam e lhe dão suporte técnico em diferentes áreas do saber, especialmente no tocante à biodiversidade, para aprimorar as instituições voltadas ao desenvolvimento necessário ao homem e aos Estados, alertando-os quanto aos perigos de degradação biosférica, se os projetos em pauta não forem bem conduzidos.

Se a década de 60 revelou o despertar do ecologismo, as duas décadas que Ihe seguiram vieram demonstrar maior conscientização da problemática homem natureza ambiente.

Não só no campo do direito internacional inúmeros acordos governamentais foram realizados, como também, por parte de organizações não governamentais, associações autodenominadas ambientalistas, a comunidade científica nas Universidades e Institutos de Pesquisa, pequenos e médios empresários em diferentes setores, associações profissionais (sindicatos ou outras), corporações multinacionais, camponeses cujo modo de atuação por um processo recente de aprendizado, enfim, passaram a ter a preocupação ambiental como um dado histórico a exigir uma tomada de posição efetiva contra a depredação e mau uso dos recursos naturais; conjugue-se a tudo isto a conscientização pela preservação de bens culturais.

B - Segunda fase: o Direito Internacional do Meio Ambiente, propriamente dito.

Estes posicionamento encontraram na Conferência Mundial de Estocolmo, em 1972, o estabelecimento de princípios básicos, sendo de real importância a aproximação da proteção ambiental àquela dos direitos humanos, com o corolário indispensável de cooperação e coordenação entre Estados e entre eles e ONGs e a responsabilidade dos Estados pelos danos que causem ao ambiente de outros Estados ou em regiões que não tenham uma jurisdição nacional (Princípios 21/26).

É bem verdade que, apesar de se ter como um marco a Conferência de Estocolmo de 72 , várias convenções internacionais de cunho ambiental já vigoravam, não só quanto ao uso de grandes espaços, proscrevendo experiências com armas nucleares na atmosfera, ou no leito do mar, fundo do oceano e seu sub-solo, particularmente, 
de âmbito global, como a Convenção sobre Responsabilidade Civil por Danos Causados por Poluição por Óleo (Bruxelas, 1969, promulgada no Brasil pelo Decreto $\mathrm{n}^{\circ} 79.437$ de 28/03/77), além de outras preservacionistas de determinadas espécies.

Todavia, os Princípios acolhidos em Estocolmo, apesar de equivalentes a resoluções, foram o esteio do atual direito internacional do meio ambiente, notadamente o Princípio 21: os Estados têm, de conformidade com a Carta das Nações Unidas e os princípios de Direito Internacional, o direito soberano de explorar seus recursos de acordo com a sua política ambiental, e a responsabilidade de garantir que atividades levadas a efeito dentro de sua jurisdição ou controle não prejudiquem o meio ambiente de outros Estados ou de áreas além dos limites da jurisdição nacional.

De tal significado este Princípio 21, que a Convenção das Nações Unidas sobre o Direito do Mar, votada em Montego Bay (Jamaica) em 1982, promulgada no Brasil pelo Decreto $n^{\circ} 99.165$ de 12/03/1990, em vigor, internamente pelo Decreto $n^{\circ} 1.530$ de 22/06/1995, em sua Parte XII, ao tratar da Proteção e Preservação de Meio Marinho, assim se expressa no art. 195:

“Ao tomar as medidas para prevenir, reduzir e controlar a poluição do meio marinho, os Estados devem agir de modo a não transferir direta ou indiretamente os danos ou riscos de uma zona para a outra ou não transformar um tipo de poluição em outro."

Desde então, foi crescente o número de convenções, tratados e acordos, tanto em nível universal (cujo maior exemplo é a Convenção de Direito do Mar), como as que se firmaram por ocasião da ECO-Rio, 92, bem como outras de caráter regional ou subregional, reflexo da sensibilização mundial com a preservação e gerenciamento dos recursos naturais, a prudência no trato dos seres vivos da natureza, do uso de tecnologias limpas na exploração daqueles recursos, em benefício da humanidade e a preocupação com o devir.

A Conferência das Nações Unidas realizada no Rio de Janeiro em 1992 conseguiu por em pauta assuntos que não foram enfrentados vinte anos antes, em Estocolmo, tais como: as mudanças climáticas e a agressão à camada de ozônio pelos clorofluorcarbonetos - os CFCs - largamente usados, mas que as indústrias produtoras alijaram qualquer tentativa de consideração no evento de 1972.

Outros temas importantes como devastação de florestas tropicais, biodiversidade e biotecnologia encontraram ambiente propício à formalização de ajustes plurilaterais, em 1992, bem como os programas da Agenda 21 e a Declaração do Rio com o conceito de desenvolvimento sustentado.

Deflui desta evolução que o direito internacional ambiental viu-se acrescido de inúmeros tratados gerais, os chamados "umbrella conventions" e outros mais específicos, tanto globais, como regionais ou bilaterais.

\section{C-Análise de suas fontes}

Qualquer que seja sua denominação, tratado, convenção, acordos firmados pelo concurso de vontades de dois ou mais Estados ou organizações internacionais, o que 
interessa é a intenção de criarem relações internacionais, regulando obrigações recíprocas. Inserem-se eles como uma das fontes principais do D. Internacional do Meio Ambiente de acordo com a letra "a", inciso 1, do art. 38 do Estatuto do CIJ. É de ponderar-se que a regra de interpretação dos tratados encontra-se no art. 31 da Convenção de Viena sobre Direito dos $\operatorname{Tratados}^{70}$, ou seja:

“1. Um tratado deve ser interpretado de boa fé, segundo o sentido comum dos termos do tratado em seu contexto e à luz de seu objeto e finalidade.

2. Para fins de interpretação de um tratado, o contexto compreende, além do texto, seu preâmbulo e anexos"...

E mais: leva-se, também, em conta, qualquer ajuste posterior entre as partes e qualquer prática seguida à aplicação do tratado, pelo qual se estabeleça o acordo das partes relativo à sua interpretação.

O incontável número de tratados e convenções multilaterais voltados à temática ambiental adquiriram tal expressão depois de Estocolmo, 72 que o Secretariado do Programa das Nações Unidas para o Meio Ambiente dispõe de edições de Registros de Tratados e Outros Acordos relativos à matéria.

Dentro da linha do art. 38 do Estatuto da CIJ, as outras duas fontes principais: costumes e princípio gerais de direito permanecem como criadores do direito internacional do meio ambiente. Convêm, no entanto, esclarecer que dada a dinâmica e rapidez da evolução das questões ambientais, o costume que perdera sua importância frente aos tratados, não deixa de conservar seu valor, mas adaptado às realidades do momento; basta que se comprove que determinada prática é generalizada e conseqüente para que se caracterize como costume internacional, sem que se exija que tal prática seja prolongada ou duradoura, como era necessário à época da vigência do Estatuto da Corte Permanente de Justiça, em 1920, de que a C.I.J. da Háia é sucessora. Na perspectiva moderna, o costume se revela na prática de determinados atos pelos Estados, em razão de convenções ou tratados gerais por eles firmados, que podem atingir terceiros Estados não participantes desses instrumentos internacionais. É o que Michel Virally ${ }^{71}$ chama de normas de caráter misto: convencionais para os Estados Partes e consuetudinárias para Estados outros.

Quanto aos princípios gerais de direito, pondo de lado as infindáveis discussões doutrinárias a respeito de sua natureza jurídica, entendemos que são princípios subjacentes aos ordenamentos jurídicos, tanto dos direitos internos, como do direito das gentes, reconhecidos pelos especialistas, pela jurisprudência internacional, inseridos, também, em convenções e tratados internacionais. São princípios que qualquer julgador se dá como apto a acolhê-los para preencher os vazios de normas expressas, mormente se fizer uma análise comparativa entre os sistemas jurídicos existentes.

70 Aberta à assinatura, em Viena, a 23.05.1969. Entrou em vigor, a 27.01.1980, internacionalmente. Não incorporada ao direito brasileiro.

71 Michel Villary - "Fuentes del Derecho Internacional", in Manual de Derecho Internacional Publico, Max Sorensen, Editor - México, Fondo de Cultura Economica, 1985 ( $3^{a}$ reedição). 
Nas questões ambientais, de preocupação mundial, tanto em normas internas, como nas internacionais, esses princípios estão presentes em expressões e conceitos como: desenvolvimento sustentado, gerações presente e futuras, dever de não poluir espaços comuns, "habitat", poluição transfronteiras, o que favorece o preenchimento de lacunas.

São de alta relevância e talvez uma das fontes mais importantes para o Direito Ambiental, as decisões dos tribunais, tanto judiciais, quanto arbitrais. Embora fonte subsidiária, os precedentes da Corte Internacional de Justiça e de sua antecessora a Corte Permanente de Justiça, constituem um referencial para elas mesmas, para decisões arbitrais e para a doutrina (outra fonte subsidiária) dos internacionalistas, na solução de contendas entre Estados; servem, também, de orientação para pendências entre outros Estados que não participaram corno litigantes numa questão, mas invocam o conteúdo da decisão em apoio do caso a ser examinado. Neste passo, é preciso esclarecer-se, o seguinte: as decisões da Corte Internacional, na previsão estatutária do art. 38 , sofrem a ressalva do art. 59 , que diz:

"A decisão da Corte só será obrigatória para as partes litigantes e a respeito
do caso em questâo".

Portanto, uma vez invocadas por outros Estados em outras pendências, tais decisões não tem força normativa como nos sistemas jurídicos de "Common Law", onde o precedente apresenta tal característica ${ }^{72}$. Mas, como auxiliar em novos julgamentos da própria Corte, ou em decisões arbitrais, ou como subsídio à doutrina, é meio relevante à determinação de regras do Direito Internacional.

O exemplo expressivo para o Direito Internacional do Meio Ambiente, referendado pela doutrina como a primeira manifestação jurídico - formal a respeito, foi o da Fundição Trail Smelter, solucionado por arbitragem "ad hoc" entre EUA e Canadá, em 1941, por poluição do ar e da água em território estadunidense, provocada pela empresa canadense. A parte mais significativa do laudo arbitral ficou assim redigida:

“... nenhum Estado tem o direito de usar seu território ou de permitir seu uso, de maneira que emanações provoquem prejuízos no território de um Estado ou às pessoas e propriedades que nele se encontram, no caso de tratar-se de conseqüências sérias e de o prejuízo ter sido provado por provas certas e conclusivas". ${ }^{73}$

Semelhante decisão arbitral foi de tal impacto para o D.I. do M.A. que influenciou a Declaração de Estocolmo, em 1972 (Princípio 21), reiterada na Declaração

72 Para melhor conhecimento dos sistemas de "Common Law", consulte-se: René David - "Os grandes sistemas do direito comparado" Meridiano, 1978, Lisboa (2 edição); Guido Fernando Silva Soares: "Common Law — Introdução ao Direito nos EUA", Editora Revista dos Tribunais, 1999. $73 \mathrm{O}$ caso relatado com riqueza de considerações por Alexandre Charles Kiss, no seu "Droit International de l'Enviromement". Paris - Éditions A. Pedonnes, 1989. 
do Rio, em 1992 (Princípio $2^{\circ}$ ), apesar de extrapolar os termos do compromisso, como lembra Kiss, vez que, do conteúdo do laudo, chega-se à conclusão da necessidade de se criarem normas específicas à proteção ambiental, revelando a indispensável colaboração e cooperação entre Estados.

Outra decisão internacional de repercussão para o D.I. do M.A. foi a pendência entre Albânia (não membro da ONU) e a Grã-Bretanha, a respeito da utilização das águas territoriais albanesas pela marinha de guerra britânica, logo após o término da $2^{a}$ Guerra Mundial, para retirada de minas no Estreito de Corfu, sem consentimento da Albânia. A situação agravou-se em 1946, quando dois contratorpedeiros britânicos se chocaram contra minas, havendo perdas materiais e humanas, sendo acionado o Conselho de Segurança da ONU que, por sua vez, convidou a Albânia a participar dos debates. O litígio veio a ser solucionado pela CIJ, em 1949, fixando-se o montante de indenizações devidas pela Albânia à Grã-Bretanha, pronunciando-se a Corte: "nenhum Estado, pode utilizar seu território para fins de prática de atos contrários ao Direito Internacional" 74 . O exemplo revela a omissão do Estado costeiro e sua responsabilidade em não advertir outros Estados a respeito de situações perigosas em áreas de sua jurisdição, violando um princípio costumeiro em D.I. Internacional, como fez a Albânia.

O caso de Corfu nos conduz a considerações atuais quanto ao uso dos espaços marítimos, à proteção e preservação do meio marinho, ao controle, prevenção e redução de todos os tipos de poluição desse meio, com a vigência de um dos tratados mais complexos aceito por mais de uma centena de países, qual seja a Convenção das Nações Unidas para o Direito do Mar, firmada na Jamaica, em Montego Bay, ao 10.12.82, já mencionada. Em suas 17 Partes com 320 artigos, a CONVEMAR exaure questões características aos vários espaços oceânicos e em seus 09 Anexos aborda temas específicos que impõem aos Estados um exame acurado à implementação das normas convencionais, tanto em nível global, quanto regional.

Os Princípios de Estocolmo (reiterados no Rio) e sumulação dos julgados internacionais que trouxemos a título ilustrativo da necessária normatização ambiental encontranrse no art. 195 da CONVEMAR, "in verbis":

"Ao tomar medidas para prevenir, reduzir e controlar a poluição do meio marinho, os Estados devem agir de modo a transferir direta ou indiretamente os danos ou riscos de uma zona para outra ou transformar um tipo de poluição em outro".

Contudo, o que cabe ainda registrar, em se falando de jurisprudência internacional, foi a criação do Tribunal Internacional do Direito do Mar (Anexo VI da CONVEMAR), com sede em Hamburgo, na Alemanha, com estatuto próprio, uma Câmara de Controvérsias dos Fundos Marinhos e Câmaras "ad hoc", instalada em 18.10.1996. Sua jurisdição (prevista no art. 21 do Anexo VI) abrange todas as

74 Para maior entendimento veja-se: "Petit Manuel de la Jurisprudence de la cour Internationale de Justice", de Eisemann. Coussirat-Coustere e Hur, Paris, Pedone, $2^{\text {a }}$ ed., 1971. 
controvérsias e pedidos que lhe sejam submetidos nos termos da Convenção, ou de quaisquer outros acordos que lhe confiram jurisdição.

De relevo, ainda, que não só os Estados terão acesso ao Tribunal, mas também entidades deles distintas cf. previsto na Parte XI, ou em qualquer questão que lhe seja submetida por acordo entre litigantes, ou que seja aceita a jurisdição pela partes em uma questão (art. 20). Deste modo, disputas internacionais poderão ser solucionadas por um sistema novo de solução de controvérsias, abrindo a possibilidade de pessoas físicas e jurídicas, bem como de organizações intergovernamentais se utilizarem de institutos de solução extrajudiciárias de litígios; e mais, para o Tribunal é desnecessária a proteção diplomática dos respectivos Estados a seus nacionais, tal como ocorre na $\mathrm{CIJ}^{75}$. Portanto, quer "ratine personae", quer "ratione materiae" há que examinar-se qualquer questão para fixação das competências previstas na CONVEMAR.

Assim sendo, formar-se-á uma jurisprudência internacional nova que ampliará o repertório de julgados tradicionais da $\mathrm{CIJ}$ e do Tribunal Arbitral explicitado no Anexo VII.

Em 01.07.1999, o Tribunal Internacional do Direito do Mar exarou seu primeiro julgamento, a respeito de transporte de óleo pelo navio Saiga, envolvendo interesses de Saint Vincent e Granadines e a Zona Econômica Exclusiva da ilha Guinea de Alcatrazes ${ }^{76}$; foram praticadas arbitrariedades pelas autoridades da Guinea, arrestando o navio, prendendo seu Mestre, a tripulação e confiscando a carga. Entendeu o Tribunal, por maioria expressiva de votos, que houve contraposição aos termos da CONVEMAR, pelo exercício arbitrário de direitos por parte da Guinea, violando os direitos de Saint Vincent e Granadines; houve violação no uso excessivo de forças, contrariando o direito internacional e por consequiência os direitos dos responsáveis pelo Saiga; determinou o pagamento de indenização pela Guinea à parte adversa, arcando cada um dos litigantes com as custas processuais.

Outra fonte subsidiária é " a doutrina dos juristas mais qualificados das diferentes nações". A prática não tem dado muita importância à doutrina dos especialistas verificando-se que a própria Corte Internacional não faz citações. Mas, se nos reportarmos à Carta da ONU, particularmente na disposição do art. $13 \S 1^{\circ}$ inciso a) verificamos que: "A Assembléia Geral iniciará estudos e fará recomendações, destinados a: a) promover cooperação internacional no terreno político e incentivar o desenvolvimento progressivo do direito internacional e a sua codificação".

No campo do D.I. do M.A. merece lembrança o papel que, de longa data, vem sendo desenvolvido pela Comissão de Direito Internacional que apresenta propostas tendentes ao desenvolvimento progressivo do D.I., buscando codificá-lo. Anualmente são feitas publicações (os Rapport) do que é discutido em sessões da Comissão,

75 Consulte-se: "Poluição Marítima e o Direito do Mar" - Georgette Nacarrato Nazo - in Rev. Literária de Direito, maio/junho, 1999, p. 16/17.

76 Através de um "Press Release", gentilmente cedido pelo Prof. Dr. Vicente Marotta Rangel, Juiz do Tribunal Internacional do Mar: pudemos ter conhecimento do caso, ainda não publicado, oficialmente. 
propostas de resoluções a serem votadas pela A.G. da ONU, após estudos elaborados por especialistas, ou mesmo projetos de convenções visando maior uniformidade no trato de determinados assuntos, embasados na melhor doutrina. É obra da CDI os trabalhos a respeito da responsabilidade internacional dos Estados (Ago - Riphagen, Arangio Ruiz) e sobre responsabilidade internacional dos Estados por atos proibidos pelo D.I. e sobre a utilização das águas internacionais para fins outros que não a navegação e que tem muito a ver com o D.l. do Meio Ambiente.

Sempre de cunho doutrinário são os estudos ou obras coletivas realizadas no âmbito de organizações intergovernamentais de que se servem os negociadores de convenções internacionais. São trabalhos de autoria indeterminada utilizados pelas secretarias dessas organizações, ou mesmo o secretariado de uma Convenção, para negociações. Também são publicados, revelando o evolver do D.I.

Merece lembrança, também, a atividade da Academia de Direito Internacional da Háia ao realizar colóquios importantes, com o mesmo objetivo; verificar o progresso do D.I. e seu desdobramento no campo específico do meio ambiente.

Outras ONGs têm prestado excelente contribuição ao enriquecimento da doutrina internacional, com a manifestação de técnicos das mais variadas áreas do saber, quer na orientação de negociações; quer respondendo a consultas, tanto de Estados, como de organizações interestatais, estabelecendo ou definindo normas à proteção ambiental. De relevo o que é elaborado por Agências Especializadas da ONU, como UNESCO, FAO, OIT, OMS, aliadas ao PNUMA, PNUD, ONUDI, a título de exemplo.

Por derradeiro, duas ONGs que se debruçam sobre estudos de D.I. em todos os seus aspectos, têm dado colaboração de altíssimo nível ao progresso e codificação do direito internacional ambiental. São elas: o "Institut de Droit International" e a "International Law Association" que produzem regras e resoluções de alcance internacional, como "ad exemplum": a) do Instituto, a Resolução de Atenas, de 1979, votada pela $20^{2}$ Comissão, que definiu a poluição transfronteiras, aos cuidar da poluição de rios e lagos, concitando os Estados a uma série de providências nas sua políticas próprias e a seus direitos na exploração de seus recursos, com efetivos controles para evitar prejuízos aos Estados vizinhos ${ }^{77}$; b) da ILA: as regras sobre as relações entre a água, outros recursos naturais e o meio ambiente, em Belgrado, 1980.

Como fonte complementar, a art. 38 da CIJ se refere a decisões "ex bono et aequo", se as partes concordarem. Indaga-se do tipo de eqüidade a que o julgador se atem: segundo a lei, "praeter legem" ou "contra legem". A primeira em nada ajuda, pois equivale à norma interpretada. A segunda, preenche a lacuna de qualquer fonte. A "contra legem" é a que visa uma decisão em discrepância com o direito positivo. À CIJ não concedem, os Estados, tal poder. Em decisões arbitrais, especialmente nos negócios internacionais, é comum os árbitros julgarem atendendo ao objetivo do negócio, de sorte a que seja útil ás partes, mesmo fora das regras de

77 Georgette Nacarato Nazo: "Meio Ambiente. Desenvolvimento e Normatização Jurídica", in Boletim da Sociedade Brasileira de Direito Internacional, jul/dez. 1994 - n $93 / 94$ - p. 61 a 68. 
direito. Para o D.I. do Meio Ambiente que se apresenta como o regramento internacional incontornável num mundo que se intercomunica, que se diz global e globalizante, mas não pode prescindir da cooperação política e da solidariedade entre nações, na busca de um justo equilíbrio para uma qualidade de vida melhor, a equiidade certamente será o meio adequado a preencher lacunas, consolidando os pressupostos em que assenta a CONVEMAR, entre eles: o reconhecimento, por consenso de seus signatários, que ela "promova os usos pacíficos dos mares $e$ oceanos, a utilização eqüitativa e eficiente de seus recursos"... "que os fundos marinhos e oceânicos e o seu subsolo para além dos limites da jurisdição nacional, bem como os respectivos recursos são patrimônio comum da humanidade e que a exploração e o aproveitamento dos mesmos fundos serão feitos em benefício da humanidade em geral, independentemente da situação geográficas dos Estados".

\section{Conclusão}

Exposta como ficou, em apertadas considerações aqui trazidas, a evolução do Direito Internacional no seu desdobramento com enfoque ambientalista, bem como da análise das fontes, como o julgador preencherá as lacunas existentes no "jus scriptum", podemos arrematar com os seguintes esclarecimento:

01 - Uma gama imensa de tratados e convenções, bem como acordos bilaterais foram feitos, versando os mais diferentes aspectos das questões ambientais.

02 . Na perspectiva do direito pátrio, tratados e convenções assinados pelo Brasil são submetidos ao Congresso Nacional, nos termos do art. $84 \S$ VII da CF, para serem aprovados. Cumprida esta formalidade, o Poder Executivo está habilitado ao depósito do documento de ratificação junto à entidade competente. Entrando em vigor internacionalmente, o Executivo promulga o tratado que passa a integrar o sistema legislativo nacional.

03. Tanto os anteriores à CF de 1988, como os promulgados posteriormente, continuam válidos no Brasil, compatíveis que sejam com o texto constitucional em vigor.

04. Aqueles já aceitos, mas ainda não vigentes internacionalmente, constituem compromissos internacionalmente assumidos pelo País, portanto, gerando responsabilidades internacionais.

05. Por força do artigo 225 da CF com incisos e parágrafos, estabeleceu, o direito brasileiro, uma ordem pública ambiental que interage com o disposto no art. $4^{\circ}$, incisos e parágrafo, nas relações internacionais.

06. Corolário dessas normativas, os tratados e convenções internacionais voltados às questões ambientais têm um cunho constitucional, o que nos leva a desconsiderar, nestas hipóteses, as discussões doutrinárias quanto à superioridade da ordem interna, ou da ordem internacional, se são ordens distintas, ou se há interação entre elas, muito ao gosto dos dualistas e monistas.

07. As lacunas por ventura existentes na legislação interna brasileira serão supridas pelas normativas internacionais. 


\section{Revista de Direito Renovar}

Carlos Alberto Menezes Direito e

Luiz Fernando Palhares

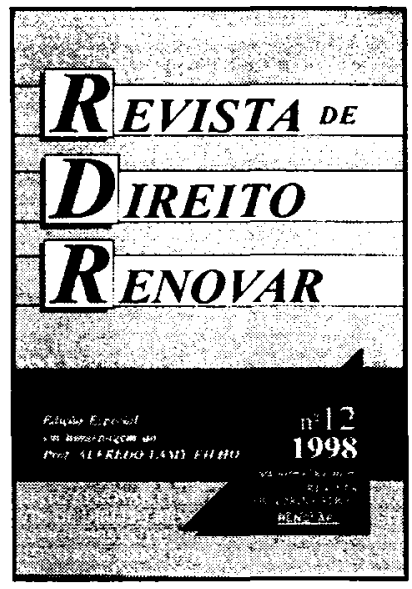

A RDR ocupa um espaço importante na produçāo jurídica brasileira. Quadrimestralmente, assegura a permanente atualidade dos trabalhos publicados, autorizando maior celeridade entre a produção científica e sua divulgação. A RDR publica, também, a jurisprudência dos Tribunais de todo o país, sendo de repositório útil para juristas, juízes, promotores, advogados e alunos, particularmente facilitada a consulta por um índice bem-estruturado. É publicação indispensável ao lado da Revista de Direito Administrativo, permitindo uma consulta ágil na doutrina e na jurisprudência mais atualizada.

$\begin{array}{lll}\text { Brochura } & \text { Form. 15x23 } 1995\end{array}$

\section{Ser Advogado \\ Técnicas e Estilo Profissionais}

Alcindo Medeiros Caldas

O autor busca, nesta obra, mexer com o orgulho e com os brios do estudante de Direito e do advogado em geral, alimentando a esperança de que, conhecendo bem a sua profissão, eles a venham respeitar e mesmo a amar, independentemente dos desafios que ela suscite e das recompensas financeiras que seja capaz de propiciar.

Ref. 0126

Brochura

Form. 14x21

232 págs.

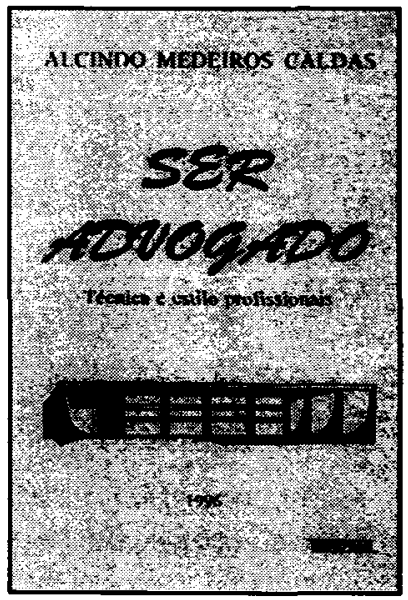

